\title{
UPAYA PENINGKATAN KOMITMEN KERJA GURU BIDANG STUDI
}

\author{
Mustaghfiroh \\ Nova Syafira Ariyanti \\ Maulana Amirul Adha \\ Sultoni \\ Manajemen Pendidikan, Fakultas Ilmu Pendidikan, Universitas Negeri Malang \\ Email: mustaghfiroh01@gmail.com
}

\begin{abstract}
The success of students depends on the commitment of the teacher, the commitment of the teacher in school shows an effort to be involved in realizing the vision and mission. The purpose of this study is to determine the factors that cause and the impact caused by the low commitment of teachers in the field of study at SMK Riyadlul Quran and strategies that can be found to solve the problem of low teacher work commitment. This study used a qualitative descriptive research design with a case study approach. Data collection techniques used in this study were interviews, observation and documentation study. In this study, the authors used the tree diagram technique to analyze the problem, analyze the causes of the problem and also analyze the impact caused by this problem. The results of this study indicate that the low commitment of teachers to work at SMK Riyadlul Quran is caused by low teacher motivation, school regulations are not implemented optimally, and lack of supervision by the principal. The formation of teacher work commitment is influenced by internal and external factors, therefore, teacher work commitment must be increased.
\end{abstract}

Keywords: work commitment, subject teacher, tree diagram technique.

\begin{abstract}
Abstrak: Keberhasilan peserta didik bergantung kepada komitmen guru, komitmen guru di sekolah menunjukkan suatu upaya untuk ikut terlibat dalam mewujudkan visi misi. Tujuan penelitian ini adalah untuk menetapkan faktor-faktor penyebab dan dampak yang disebabkan oleh rendahnya komitmen guru bidang studi di SMK Riyadlul Quran dan strategi yang dapat ditemukan untuk memecahkan masalah rendahnya komitmen kerja guru. Penelitian ini menggunakan desain penelitian deskriptif kualitatif dengan pendekatan studi kasus. Teknik pengumpulan data yang digunakan dalam penelitian ini adalah wawancara, observasi dan studi dokumentasi. Dalam penelitian ini, penulis menggunakan teknik tree diagram untuk menganalisis masalah, menganalisis penyebab masalah dan juga menganalisis dampak yang disebabkan oleh masalah ini. Hasil penelitian ini menunjukkan bahwa rendahnya komitmen guru dalam bekerja di SMK Riyadlul Quran disebabkan oleh motivasi guru rendah, peraturan sekolah tidak diterapkan secara optimal, dan kurangnya pengawasan oleh kepala sekolah. Pembentukan komitmen kerja guru dipengaruhi oleh faktor internal dan eksternal, oleh karena itu, komitmen kerja guru harus ditingkatkan.
\end{abstract}

Kata kunci: komitmen kerja, guru bidang studi, teknik diagram pohon

Masalah mutu pendidikan adalah masalah yang sedang hangat-hangatnya dalam dunia pendidikan kita, terutama berkaitan dengan rendahnya mutu pendidikan yang terdapat pada setiap jenjang pendidikan yang ada di Indonesia terutama dalam pendidikan dasar dan pedidikan menengah. Pengelolaan pendidikan dengan mewujudkan lingkungan belajar yang efektif serta kondusif secara berkelanjutan merupakan salah satu upaya peningkatan mutu pendidikan di suatu satuan pendidikan (Adha, Supriyanto, et al., 2019; Saputra et al., 2019). Pengelolaan pendidikan dalam hal ini berkaitan dengan komitmen dalam organisasi. Komitmen organisasi adalah suatu aspek yang begitu penting yang wajib ada dalam suatu organisasi. Menurut Greenberg dan Baron (2003) komitmen 
organisasi adalah suatu bentuk keterlibatan karyawan dalam organisasi yang digelutinya serta mempunyai keinginan untuk ikut serta dalam memajukan organisasi, dimana terdapat kesediaan dan kesetiaan karyawan untuk kesukarelaan dalam melakukan pekerjaan dengan maksimal dalam organisasi tempat mereka bekerja. Sedangkan menurut Luthans (2011), komitmen organisasi merupakan keinginan seseorang untuk tetap bertahan dalam organisasi tertentu dan mempunyai keinginan untuk mewujudkan tujuan organisasi tersebut.

Komitmen organisasi sangat dibutuhkan dalam suatu organisasi pendidikan karena seorang guru yang memiliki komitmen kerja yang tinggi lebih cenderung memiliki perilaku yang profesional dan juga menjujung tinggi aturan-aturan maupun nilai-nilai yang telah disepakati dalam organisasi yang digelutinya (Ariyanti et al., 2019; Thien et al., 2014). Sebagai bentuk keterikatan seorang guru dengan organisasi tertentu, maka ia akan memiliki perasaan, sikap, serta pandangan tertentu tentang kondisi lingkungan organisasi (Darmaji et al., 2020; Juharyanto et al., 2020). Kondisi ini akan membentuk perasaan, sikap, dan persepsi yang bekaitan dengan kondisi lingkungan dalam organisasi, baik dalam wujud kegiatan organisasi, nilai ataupun norma yang ditetapkan dan berlaku dalam organisasi. Menurut Wibowo dalam (Susana, 2018) komitmen organisasi memiliki beberapa komponen, diantaranya adalah affectif commitment, normative commitment dan continuance commitment, dan masing-masing tipe tersebut dipengaruhi oleh faktor yang berbeda-beda. Affectif commitment dipengaruhi oleh macam-macam karakteristik personal seperti halnya kepribadian seseorang, serta pengalaman kerja ditempat sebelumnya. Sedangkan normative commitment dipengaruhi oleh proses sosialisasi yang berkaitan dengan keyakinan yang seharusnya diterima oleh karyawan sebagai imbalan atas apa yang telah mereka lakukan terhadap organisasi. Dan, continuance commitment dipengaruhi oleh kemauan dari individu itu sendiri untuk tetap bertahan dalam suatu organisasi dikarenakan kurangnya alternatif pekerjaan lain.
Komitmen kerja adalah kesanggupan seseorang untuk mewujudkan dan melakukan pencapaian tujuan organisasi secara umum (Hasibuan, 2016). Komitmen kerja guru yang tinggi merupakan aspek yang wajib ada dalam sebuah organisasi sekolah, karena terciptanya komitmen kerja yang tinggi akan berpengaruh terhadap situasi kerja yang profesional dan sesuai dengan apa yang diharapkan (Collie et al., 2011). Salah satu cara untuk mengukur keberhasilan suatu organisasi pendidikan dalam mengembangkan kualitas peserta didik adalah dengan mengukur kualitas para pengajarnya (Adha, Gordisona, et al., 2019; Dwyer \& Stufflebeam, 2013). Keberhasilan peserta didik adalah bergantung kepada kualitas para pengajarnya (Ariyanti et al., 2020). Karena pendidik merupakan pihak yang paling banyak berhubungan langsung dengan siswa dalam proses pembelajaran di sekolah. Dengan demikian, komitmen kerja guru dalam suatu organisasi sekolah adalah keinginan yang berasal dari dalam diri guru untuk mempertahankan keanggotaannya dan turut ikut bersedia berusaha untuk mencapai tujuan organisasi dan juga turut serta dalam meningkatkan kualitas pendidikan yang lebih baik untuk kedepannya.

Komitmen seseorang terhadap organisasi tempat dia bekerja menunjukkan suatu upaya dari seseorang tersebut untuk ikut terlibat dalam mewujudkan visi misi organisasi tersebut. Srinalina (2015) berpendapat bahwa kinerja guru pada dasarnya adalah suatu unjuk kerja yang dilakukan oleh seorang guru dalam melaksanakan tugas sebagai seorang pendidik. Oleh karena itu, sudah seharusnya seorang guru mempunyai kinerja yang tinggi serta menunjukkan komiitmen kerja yang tinggi dalam rangka membangun sekolah yang yang berkualitas dan juga berintegritas tinggi (Buchanan, 2015; Collie et al., 2011; Thien et al., 2014). Guru di lingkungan Sekolah Menengah Kejuruan swasta berbasis Islam memiliki karakteristik dengan guru yang bekerja di sekolah umum, hal tersebut menunjukkan perlunya dilakukan identifikasi penyebab rendahnya komitmen kerja guru serta dampaknya kepada peserta didik, dan strategi untuk penyelesaiannya. Tujuan dari penelitian ini adalah untuk menemukan 
dampak dan sebab yang menyebabkan rendahnya komitmen kerja beberapa guru sehingga dapat ditemukan titik terang penyelesaian masalah tersebut. Hasil dari penelitian ini tidak hanya berguna untuk sekolah diteliti, tetapi juga bisa digunakan acuan oleh sekolah manapun yang memiliki permasalahan yang sama.

\section{METODE}

Penelitian ini menggunakan rancangan penelitian deskriptif kualitatif dengan pendekatan studi kasus. Hal ini dilakukan karena peneliti ingin menggambarkan atau melukiskan fakta-fakta ataupun keadaan sesuai dengan yang terjadi (Ulfatin, 2015). Penelitian ini bertujuan untuk mengetahui faktor-faktor penyebab dan dampak yang ditimbulkan dari rendahnya komitmen kerja guru di SMK Riyadlul Quran Kec. Ngajum, Kab. Malang dan juga strategi penyelesaian masalah tersebut. Teknik pengumpulan data yang digunakan yakni wawancara, observasi dan studi dokumentasi. Key informan dalam penelitian ini adalah Kepala Sekolah, dengan guru dan siswa sebagai informan tambahan. Studi dokumentasi, yang digunakan yakni dokumen analisis terkait rekap daftar hadir guru di TU dan daftar hadir guru di kelas, serta melakukan observasi secara langsung terkait kehadiran guru dan kepulangan guru. Pengecekan keabsahan data dilakukan kredibilitas. Kredibilitas tersebut meliputi triangulasi, meningkatkan ketekunan, serta kecukupan referensi. Adapun teknik analisis data yang dilakukan dalam pendekatan kualitatif deskriptif ini menggunakan analisis Miles et al. (2014) yaitu mulai dari reduksi data, penyajian data, dan penarikan kesimpulan/verifikasi.

\section{HASIL}

Dalam penelitian ini, penulis mengamati masalah yang ada di sekolah menggunakan teknik analisis diagram pohon masalah (tree diagram) atau sering juga disebut diagram sistematik, analisis pohon, pohon analitis, atau diagram hirarkhi. Menurut Sutjiaji (2009) diagram pohon adalah suatu bentuk diagram yang dirancang secara detail dan memiliki hubungan satu sama lain. Diagram pohon dibuat dengan tujuan untuk menemukan hasil akhir dengan menelusuri kembali secara detail bagaimana hasil akhir tersebut dapat ditemukan. Dalam hal ini, diagram pohon dapat menjelaskan secara rinci tentang apa yang kita butuhkan dan hasil akhir yang didapatkan, sehingga teknik ini dapat kita lakukan untuk mendapatkan hasil yang kita inginkan (Dey, 2012).

Diagram pohon tidak hanya dapat digunakan untuk menganalisis satu kasus, melainkan dapat juga digunakan untuk menganalisis beberapa kasus yang saling berhubungan (Dey, 2012). Seperti namanya, diagram pohon berbentuk seperti pohon yang memiliki satu batang dahan yang mencabang menjadi dua atau lebih. Begitupun juga dengan permasalahan yang akan dianalisis menggunakan diagram pohon, yaitu terdiri dari satu satu kategori besar yang kemudian dibagikan menjadi beberapa cabang untuk lebih terperinci dan lebih detail. Diagram pohon dapat membantu kita untuk menyederhanakan suatu masalah yang rumit serta kompleks dan mempermudah kita untuk mendapatkan gambaran terhadap suatu permasalahan yang sedang dihadapi (J. Kovacic, 2010). Menurut Dale (dalam Nasution, 2015) diagram pohon masalah adalah alat yang digunakan oleh manajer untuk membuat rencana perbaikan proses berdasarkan input dari pelanggan, yaitu dengan fokus pada tujuan utama dan menjadikannya sebagai sasaran tugas yang perlu dilakukan.

Menurut Azizah, (2014) pohon masalah (problem tree) adalah sebuah pendekatan atau metode yang digunakan untuk mengidentifikasi penyebab suatu masalah terjadi. Analisis pohon masalah dilakukan dengan cara membentuk pola pikir secara sistematis tentang komponen sebab akibat yang berkaitan dengan masalah yang sedang diteliti. Pohon masalah memiliki 3 bagian, yaitu bagian batang, bagian akar dan bagian cabang. Bagian batang perupakan gambaran dari masalah utama dan akar merupakan menyebabkan masalah inti terjadi, sedangkan cabang adalah dampaknya. Silverman (dalam 
Azizah, 2014) menyatakan bahwa istilah diagram pohon masalah (Tree Diagram) adalah suatu diagram yang sistematik yang dirancang untuk mengurutkan hubungan sebab-akibat. Berdasarkan beberapa pendapat ahli sebelumnya, dapat disimpulkan bahwa diagram pohon masalah (Tree Diagram) adalah suatu metode pemecahan masalah dengan mencari hubungan sebabakibat dari suatu masalah. Sehingga dapat ditemukan teknik pemecahan masalah tersebut.

Data yang diperoleh selama penelitian di SMK Riyadlul Quran, dilakukan analisis dengan menggunakan teknik diagram pohon. Berdasarkan data di lapangan menunjukkan rendahnya komitmen kerja beberapa guru bidang studi yang ada di SMK Riyadlul Quran sehingga berdampak buruk terhadap kualitas hasil pembelajaran para peserta didik dan berdampak juga pada kualitas output/ lulusan sekolah. Rendahnya ketidakhadiran guru menjadi salah satu penyebab kecilnya angka partisipasi murid. Bahkan, ketidakhadiran guru menjadi alasan siswa tak bersekolah. Dalam hal ini, ketidakhadiran guru mengindikasikan komitmen yang rendah yang dimiliki oleh seorang pengajar dalam menjalankan tugasnya. Terdapat beberapa guru yang tidak melaksanakan kewajibannya secara profesional seperti sering tidak masuk, tidak membuat rencana pembelajaran, serta acuh tak acuh terhadap program atau kegiatan yang dibuat oleh sekolah, sehingga kondisi institusi sekolah tidak kondusif. Namun sebaliknya ada juga guru atau staf yang bekerja dengan penuh semangat, disiplin dan selalu peka terhadap program atau kegiatan yang dibuat oleh sekolah. Fakta ini hanyalah sebagian dari kompleksitas permasalahan yang selalu dihadapi oleh kepala sekolah SMK Riyadlul Quran. Berikut adalah hasil analisa terhadap data mengenai faktor-faktor yang mempengaruhi dan juga dampak apa saja yang ditimbulkan dari rendahnya komitmen kerja guru di SMK Riyadlul Quran dengan menggunakan menggunakan teknik diagram pohon masalah (Tree Diagram), secara visual Gambar 1 berikut menunjukkan hasil identifikasi penyebab suatu masalah.

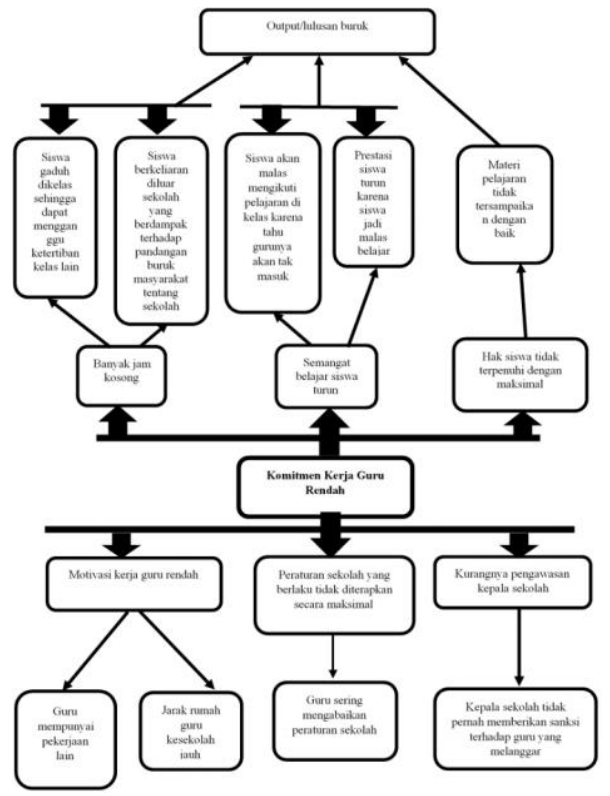

\section{Gambar 1 Hasil Analisis Tree Diagram SMK Riyadlul Quran}

\section{PEMBAHASAN}

Gejala-gejala yang ditimbulkan oleh komitmen kerja guru rendah antara lain adalah; (1) guru tidak bekerja dengan sungguh-sungguh, (2) guru tidak memberikan pelayanan terbaik, (3) tanggung jawab guru rendah, (4) tingkat kedisiplinan guru juga rendah, (5) guru sering izin tidak masuk dan (6) guru sering mengabaikan peraturan 
sekolah. Adapun, dampak negatif yang ditimbulkan dari kesenjangan ini, diantaranya adalah; (1) banyak jam kosong, (2) semangat belajar siswa turun, (3) hak siswa tidak terpenuhi dengan maksimal. Selain itu, terdapat juga dampak yang lebih rinci yang ditimbulkan dari dampak diatas. Banyaknya jam kosong dapat menyebabkan (1) siswa gaduh dikelas sehingga dapat mengganggu ketertiban kelas lain (2) siswa berkeliaran diluar sekolah yang berdampak terhadap pandangan buruk masyarakat tentang sekolah. Selanjutnya, semangat belajar siswa turun dapat menyebabkan (1) siswa akan malas mengikuti pembelajaran di kelas karena tahu gurunya akan tak masuk, (2) prestasi siswa turun karena siswa jadi malas belajar. Serta hak siswa tidak terpenuhi dengan maksimal dalam proses pembelajaran berdampak pada materi pelajaran tidak tersampaikan dengan baik, sehingga materi yang didapatkan peserta didik tidak sesuai dengan harapan. Hal ini sangat merugikan pihak sekolah maupun orangtua peserta didik.

Menurut Saragih (2012), permasalahan yang sedang dialami guru menengah saat ini adalah rendahnya komitmen organisasi. Permasalahan seperti ini sebenarnya tidak hanya terjadi di sekolah menengah ini, melainkan hampir seluruh sekolah menengah yang lain juga memiliki masalah yang sama. Masalah seperti harus mendapat perhatian khusus dari pihak organisasi maupun dari pihak pemerintah, yang menjadi penyebab terjadi kesenjangan dan apa saja dampak yang ditimbulkan dari kesenjangan ini. Masalah redahnya komitmen kerja guru bidang studi di SMK Riyadlul Quran disebabkan oleh beberapa faktor, diantaranya adalah (1) Motivasi kerja guru rendah, (2) Peraturan sekolah yang berlaku tidak diterapkan secara maksimal, dan (3) Kurangnya pengawasan kepala sekolah. Adapun rendahnya motivasi kerja guru disebabkan oleh dua faktor yaitu guru mempunyai pekerjaan lain dan jarak rumah guru ke sekolah jauh. Sedangkan Peraturan sekolah yang berlaku tidak diterapkan secara maksimal disebabkan oleh guru sering mengabaikan peraturan sekolah. Serta Kurangnya pengawasan kepala sekolah disebabkan oleh kepala sekolah tidak pernah memberikan sanksi terhadap guru yang melanggar.

Berbagai cara dilakukan untuk meningkatkan mutu guru yang telah bertugas di sekolah melalui pendidikan dalam jabatan (in-service training) (Naro, 2017). Tujuannya adalah untuk meningkatkan keterampilan mengajar, penguasaan materi ajar, serta komitmen dan motivasi guru dalam melakukan proses pembelajaran (Essel et al., 2009). Beberapa faktor yang dapat menjadi pendukung dalam peningkatan komitmen professional guru antara lain, motivasi kerja, sertifikasi pendidik, kepemimpinan kepala sekolah, dan peranan pengawas pendidikan (Jokomarsono, 2019; Naro, 2017). Pada uraian diatas sudah dijelaskan tentang dampak-dampak yang ditimbulkan dari masalah rendahnya komitmen kerja guru dan juga faktor-faktor penyebab timbulnya masalah tersebut. Maka strategi yang diambil oleh Kepala Sekolah dalam upaya meningkatkan komitmen kerja guru bidang studi antara lain:

1. Kepala sekolah memberikan reward kepada guru yang disiplin dan mempunyai komitmen kerja tinggi, hal ini bertujuan untuk meningkatkan motivasi guru dalam menjalankan pekerjaannya.

2. Kepala sekolah bertindak tegas dan memberikan sanksi terhadap guru yang lalai atas tanggungjawabnya.

3. Sekolah menyediakan fingerprint.

4. Kepala sekolah lebih memperhatikan guruguru yang kurang memiliki motivasi dalam mengajar dengan terus memberikan masukan, menegur setiap ada pelanggaran dalam hal kedisiplinan.

5. Pihak sekolah mengusahakan dalam hal pemenuhan fasilitas media pembelajaran yang dibutuhkan oleh guru, guna untuk membangun motivasi guru dalam kegiatan pembelajaran dikelas.

\section{KESIMPULAN}

Guru merupakan pihak yang sangat berpengaruh dalam berjalannya proses pembelajaran. Hasil penelitian ini menunjukkan bahwa rendahnya komitmen 
guru dalam bekerja di SMK Riyadlul Quran disebabkan oleh; (1) motivasi kerja guru rendah, (2) peraturan sekolah yang berlaku tidak diterapkan secara optimal, dan (3) kurangnya pengawasan oleh kepala sekolah Terbentuknya komitmen kerja seorang guru dipengaruhi oleh beberapa faktor, diantaranya andalah faktor internal dan juga faktor eksternal. Faktor internal meliputi faktor yang berasal dari dalam diri seseorang, sedangkan faktor eksternal adalah faktor yang berasal dari luar lingkungan organisasi. Komitmen kerja guru yang tinggi sangatlah dibutuhkan dalam sebuah organisasi sekolah, karena dengan terwujudnya komitmen kerja yang tinggi akan mempengaruhi situasi kerja dan sesuai apa yang diharapkan. Strategi yang dapat dilakukan oleh Kepala Sekolah dalam upaya meningkatkan komitmen kerja guru bidang studi antara lain: (1) Kepala sekolah memberikan reward kepada guru yang disiplin dan mempunyai komitmen kerja tinggi, (2) Kepala sekolah bertindak tegas dan memberikan sanksi terhadap guru yang lalai atas tanggungjawabnya, (3) Sekolah menyediakan fingerprint, (4) Kepala sekolah lebih memperhatikan guru-guru yang kurang memiliki motivasi dalam mengajar dengan terus memberikan masukan, dan pembinaan, dan (5) Pihak sekolah mengusahakan dalam hal pemenuhan fasilitas media pembelajaran yang dibutuhkan oleh guru, guna untuk membangun motivasi guru dalam kegiatan pembelajaran dikelas.

\section{DAFTAR RUJUKAN}

Adha, M. A., Gordisona, S., Ulfatin, N., \& Supriyanto, A. (2019). Analisis Komparasi Sistem Pendidikan Indonesia dan Finlandia. Jurnal Studi Manajemen Pendidikan, 3(2), 145-160. https://doi.org/http://dx.doi.org/10.29240 /jsmp.v3i2.110

Adha, M. A., Supriyanto, A., \& Timan, A. (2019). Strategi Peningkatan Mutu Lulusan Madrasah Menggunakan Diagram Fishbone. Tarbawi: Jurnal Keilmuan Manajemen Pendidikan, 5(01), 11-22. https://doi.org/10.32678/tarbawi.v5i01.1
794

Ariyanti, N. S., Adha, M. A., Sumarsono, R. B., \& Sultoni, S. (2020). Strategy to Determine the Priority of Teachers' Quality Problem Using USG (Urgency, Seriousness, Growth) Matrix. International Research-Based Education Journal, 2(2), 54-62. https://doi.org/10.17977/um043v2i2p5462

Ariyanti, N. S., Supriyanto, A., \& Timan, A. (2019). Kontribusi Kepala Sekolah Berdasarkan Ketidaksesuaian Kualifikasi Guru Untuk Meningkatkan Kualitas Sekolah (Studi Kasus di SD Islam Terpadu Robbani Singosari Kabupaten Malang). Nidhomul Haq: Jurnal Manajemen Pendidikan Islam, 4(2), 157-168.

Azizah. (2014). Perencanaan Dan Evaluasipohon Masalah. Universitas Airlangga.

Buchanan, R. (2015). Teacher Identity and Agency in an Era of Accountability. Teachers and Teaching: Theory and Practice, 21(6), 700-719. https://doi.org/10.1080/13540602.2015. 1044329

Collie, R. J., Shapka, J. D., \& Perry, N. E. (2011). Predicting Teacher Commitment: The Impact of School Climate and Social Emotional Learning. Psychology in the Schools, 48(10), 1034-1048.

https://doi.org/10.1002/pits.20611

Darmaji, Supriyanto, A., Timan, A., \& Adha, M. A. (2020). Sistem Penjaminan Mutu Internal Sekolah di Satuan Pendidikan Dasar (Studi Kasus di SD Plus AlKautsar Malang). Jurnal Pendidikan Dasar Nusantara, 5(2), 172-186.

Dey, P. K. (2012). Project Risk Management using Multiple Criteria Decision-Making Technique and Decision Tree Analysis: A Case Study of Indian Oil Refinery. Production Planning and Control, 23(12), 903-921. 
https://doi.org/10.1080/09537287.2011. 586379

Dwyer, C. A., \& Stufflebeam, D. (2013). Teacher Evaluation. In Handbook of Educational Psychology. Routledge. https://doi.org/10.4324/978020305387432

Essel, R., Badu, E., \& Saah, A. A. (2009). InService Training: an Essential Element in the Professional Development of Teachers. Malaysian Journal of Distance Education, 11(2), 55-64.

Greenberg, J., \& Baron, R. A. (2003). Behavior in Organization International Edition. Prentice Hall.

Hasibuan, H. . (2016). Manajemen Sumber Daya Manusia (Revisi). Bumi Aksara.

J. Kovacic, Z. (2010). Early Prediction of Student Success: Mining Students Enrolment Data. Proceedings of the 2010 InSITE Conference. https://doi.org/10.28945/1281

Jokomarsono, W. (2019). Supervisi Edukatif Kolaboratif Secara Periodik Sebagai Upaya Peningkatan Kinerja Guru dalam Pembelajaran. Jurnal Dinamika Manajemen Pendidikan, 4(1), 42-59. https://journal.unesa.ac.id/index.php/jd mp/article/view/5302/2985

Juharyanto, Bafadal, I., Arifin, I., Saputra, B. R., \& Adha, M. A. (2020). The Use of Conventional Communication Technology as an Effective Principal Leadership Strategy in Strengthening the Role of Multi-Stakeholder's Forum for School Quality improvement. Elementary Education Online, 19(4), 1963-1973.

https://doi.org/10.17051/ilkonline.2020.7 62773

Luthans, F. (2011). Organizational Behavior. McGraw Hill.

Miles, M. B., Huberman, A. M., \& Saldana, J. (2014). Qualitative Data Analysis. Sage.
Naro, W. (2017). Komitmen Profesi Dan Pengaruhnya Terhadap Kompetensi Profesional Guru Pada Madrasah Tsanawiyah Di Kota Makassar. Inspiratif Pendidikan, $6(1), \quad 35$. https://doi.org/10.24252/ip.v6i1.3581

Nasution, N. M. (2015). Manajemen Mutu Terpadu (Total Quality Management). Ghalia Indonesia.

Saputra, B. R., Adha, M. A., Ariyanti, N. S., \& Gunawan, I. (2019). Tips for Principal in Managing One Roof School ( SATAP) in Underdeveloped Area. 4th International Conference on Education and Management (CoEMA 2019), December.

https://doi.org/10.2991/coema19.2019.10

Saragih, R. P. (2012). Pengaruh Persepsi Guru tentang Kepemimpinan Kepala Sekolah, Tim Kerja dan Kepuasan Kerja terhadap Komitmen Organisasi. Universitas Negeri Medan.

Srinalina. (2015). Faktor-Faktor Penyebab Rendahnya Kinerja Guru dan Korelasinya terhadap Pembinaan Siswa: Studi Kasus di Sman 1 Darul Imarah Aceh Besar. Jurnal IImiah Didaktika, 15(2), 193-207.

Susana. (2018). Supervisi Akademik dan Komitmen Kerja Guru terhadap Kinerja Mengajar Guru. Jurnal Administrasi Pendidikan, 25(1), 120-128.

Sutjiaji, A. D. (2009). Aplikasi Network Pohon dalam Tree Diagram. Institut Teknologi Bandung.

Thien, L. M., Abd Razak, N., \& Ramayah, T. (2014). Validating Teacher Commitment Scale Using a Malaysian Sample. SAGE Open, 4(2), 1-9. https://doi.org/10.1177/2158244014536 744

Ulfatin, N. (2015). Metode Penelitian Kualitatif di Bidang Pendidikan: Teori dan Aplikasinya. Media Nusa Creative. 